J Am Soc Hypertens. 2016 August ; 10(8): 625-632.e1. doi:10.1016/j.jash.2016.05.012.

\title{
Gender, Race, Age, and Regional Differences in the Association of Pulse Pressure with Atrial Fibrillation: The Reasons for Geographic and Racial Differences in Stroke Study
}

\author{
Lama Ghazi, MD¹, Monika M. Safford, MD¹, Yulia Khodneva, MD, PhD¹, Wesley T. O’Neal, \\ MD², Elsayed Z. Soliman, MD, MSC, $\mathbf{M S}^{2}$, and Stephen P Glasser, MD' \\ ${ }^{1}$ Department of Medicine, University of Alabama at Birmingham, Birmingham, Alabama, USA \\ ${ }^{2}$ Department of Internal Medicine, Wake Forest School of Medicine, Winston-Salem, North \\ Carolina
}

\section{Abstract}

Background-Pulse pressure (PP) has been associated with atrial fibrillation (AF) independent of other measures of arterial pressure, and other AF risk factors. However, the impact of gender, race, age, and geographic region on the association between $\mathrm{PP}$ and $\mathrm{AF}$ is unclear.

\begin{abstract}
Method-A cross-sectional study of data from 25,109 participants (65 99 years of age), 54\% women, $40 \%$ black) from the Reasons for Geographic and Racial Differences in Stroke (REGARDS) study recruited between 2003 and 2007 were analyzed. AF was defined as a selfreported history of a previous physician diagnosis, or presence of AF on ECG. Multivariable logistic regression models were used to calculate the odds ratio for AF. Interactions for age $(<$ and $\geq 75$ years), gender, race, and region were examined in the multivariable adjusted model.
\end{abstract}

Results-The prevalence of AF increased with widening PP (7.9\%, 7.9\%, 8.4\%, and 11.6\%, for PP <45, 45-54.9, 55-64.9, and $\succ 65 \mathrm{~mm} \mathrm{Hg}$, respectively, [p for trend <0.001]), but attenuated with adjustment. No differences by gender, race, and region were observed. However, there was evidence of significant effect modification by age (interaction $\mathrm{p}=0.0002$ ). For those $<75$ years of age, PP $\searrow 65 \mathrm{~mm} \mathrm{Hg}$ compared to $\mathrm{PP}<45 \mathrm{~mm} \mathrm{Hg}$ was significantly associated with higher risk of AF in both the unadjusted and multivariable adjusted models (Odds Ratio 1.66 [95\% CI 1.42-1.94] and 1.32 [95\% CI 1.03-1.70], respectively). In contrast, higher PP (55-64.9 mm Hg) among those $\geq 75$ years of age was significantly associated with a lower risk of AF.

Conclusion-The relationship between PP and AF may differ for older vs. younger individuals.

\footnotetext{
Corresponding Author: Lama Ghazi, MD, Department of Medicine- Hypertension Program, University of Birmingham Alabama, Birmingham, AL35294, Phone: +1.205.934.9281, Fax: +1.205.934.1302, 1ghazi@uab.edu.

Publisher's Disclaimer: This is a PDF file of an unedited manuscript that has been accepted for publication. As a service to our customers we are providing this early version of the manuscript. The manuscript will undergo copyediting, typesetting, and review of the resulting proof before it is published in its final citable form. Please note that during the production process errors may be discovered which could affect the content, and all legal disclaimers that apply to the journal pertain.

Financial disclosure: none

Conflict of interest: none
} 


\section{Keywords}

atrial fibrillation; pulse pressure; age

Pulse pressure (PP) is a surrogate measure of arterial stiffness, and both have been linked to cardiovascular disease (CVD) outcomes ${ }^{1-7}$. Atrial fibrillation (AF) is the most common chronic cardiac arrhythmia in adults and is associated with adverse CVD events ${ }^{8-10}$. In the US, AF prevalence is expected to increase from 2.3 million currently to 5.6 million by the year 2050 and thereby require more healthcare utilization irrespective of gender or race ${ }^{8,11}$. In some studies, PP has been associated with new onset AF independent of other measures of arterial pressure and other previously recognized AF risk factors ${ }^{12}$, 13 . In the Framingham Heart Study, each $20 \mathrm{~mm} \mathrm{Hg}$ increase in the difference between systolic blood pressure (SBP) and diastolic blood pressure (DBP) was associated with a $24 \%$ increase in the risk of developing AF, even after adjusting for average arterial pressure and AF risk factors ${ }^{12}$. Elevated PP is associated with increased aortic stiffness which increases with age and appears to be modifiable ${ }^{14,15}$. These findings suggest that PP may represent a potentially modifiable risk factor, and that lifestyle modifications, including weight loss, exercise, salt reduction, moderate alcohol consumption ${ }^{16}$, or therapy aimed specifically at reducing or limiting the increase in PP with advancing age has the potential to reduce the substantial and rapidly growing incidence of $\mathrm{AF}$ in our aging society.

Studies that have addressed the risk of AF in African Americans (AAs) suggest that they have a lower prevalence of $\mathrm{AF}$ compared to whites, despite higher prevalence of AF risk factors. This is referred to as the AF paradox, and no good explanation has been elucidated, although detection bias, survival bias, and differential susceptibility have been suggested ${ }^{17}$. In the REasons for Geographic And Racial Differences in Stroke (REGARDS) study, the relative risk of $\mathrm{AF}$ in AA versus whites differed according to the approach to detect $\mathrm{AF}$. Adding electrocardiographically detected AF to self-report diminished the association between race and $\mathrm{AF}^{18}$. Our aim was to better understand if the $\mathrm{AF}$ paradox holds true when studying the association between PP and AF, or if this paradox could be explained by PP differences by race ${ }^{18}$. Prior studies have shown that gender is related to risk of developing AF. AF prevalence increases with age, but after adjusting for AF risk factors including age, men compared to women had a 1.5 fold increased risk of developing $A F{ }^{19}$. Furthermore, women develop AF at an older age then men and have high CVD risk once AF develops including greater rates of stroke and lower quality of life than men ${ }^{20-23}$. Moreover, evidence from population studies that evaluated gender, race, age, or regional differences in the relationship between $\mathrm{AF}$ and $\mathrm{PP}$ in a cohort that includes a large number of AA and women is lacking. Therefore, we examined the cross-sectional association between PP and AF in the REGARDS study.

\section{METHODS}

\section{Study Population and Design}

Details of the REGARDS study have been published previously ${ }^{24}$. Briefly, the REGARDS study was designed to understand mechanisms leading to regional and racial disparities in 
stroke mortality. The study over-sampled AA and residents of the stroke belt (North Carolina, South Carolina, Georgia, Alabama, Mississippi, Tennessee, Arkansas, and Louisiana). Between January 2003 and October 2007, participants were recruited from a commercially available list of residents using postal mailings and telephone data. Trained interviewers used a computer-assisted telephone interview (CATI) system to obtain demographic information and medical histories. An in-home physical examination including blood pressure measurements, electrocardiogram recording, information on medications, blood and urine samples was performed 3-4 weeks after the telephone interview.

For this study, 5130 of the study's 30,239 participants were excluded because of missing baseline covariates $(n=4372)$ or participants missing AF data $(n=702)$. The remaining 25,109 participants were included in the final analysis (Figure 1).

\section{Pulse Pressure}

Similar to other published studies, PP was divided into 4 groups: < $45 \mathrm{~mm} \mathrm{Hg}, 45-54.9 \mathrm{~mm}$ $\mathrm{Hg}, 55-64.9 \mathrm{~mm} \mathrm{Hg}$, and $\geq 65 \mathrm{~mm} \mathrm{Hg} .{ }^{6} \mathrm{SBP}$ and DBP were measured by trained technicians using an aneroid sphygmomanometer. The SBP and DBP was recorded as the average of two measurements taken according to the recommendations of the seventh Joint National Committee on Prevention, Detection, and Treatment of High Blood Pressure (JNC 7). ${ }^{25}$

\section{Atrial Fibrillation}

Details on AF ascertainment have been published previously ${ }^{26}$. Briefly, AF was identified from a self-reported history of a physician diagnosis of AF obtained during CATI surveys and by the study-scheduled ECG recorded during the in-home visit that was then read centrally by trained ECG technicians blinded to the clinical data.

\section{Covariates}

Age, gender, race, income, education, region, alcohol habits, and smoking status were selfreported. Annual household income was dichotomized at $\$ 35,000$, and education was dichotomized as achieving at least a high school diploma vs. less than a high school education. Cigarette smokers were categorized into never, past (at least 100 cigarettes in their lifetime), and current. Alcohol use was classified as heavy ( $>2$ drinks/day for men and $>1$ drink/day for women), moderate ( 1 to 2 drinks/day for men and 1 drink/day for women), and none ${ }^{27}$. Hypertension was defined as SBP $\geq 140 \mathrm{mmHg}$ or DBP $\geq 90 \mathrm{mmHg}$, respectively, or self-reported use of anti -hypertensive medications, which were classified according to the Medispan Therapeutic Classification system ${ }^{28}$. Vascular disease was defined as self-reported history of stroke, peripheral artery disease or aortic aneurysm. Coronary heart disease was defined by self-reported history of myocardial infarction (MI), coronary artery bypass grafting, coronary angioplasty or stenting, or evidence of MI on the baseline electrocardiogram. Left ventricular hypertrophy was defined by the Sokolow-Lyon Criteria $^{29}$. Diabetes was defined as fasting glucose level $\geq 126 \mathrm{mg} / \mathrm{dL}$ (non-fasting glucose, $\geq 200 \mathrm{mg} / \mathrm{dL}$ ) or a history of taking diabetes medications. Renal function was assessed using urinary albumin to creatinine ratio (ACR). ACR levels $>30 \mathrm{mg} / \mathrm{g}$ were considered as renal dysfunction ${ }^{30}$. Blood and urine markers included levels of total cholesterol, high-density 
lipoprotein (HDL) cholesterol, and high-sensitivity C-reactive protein (CRP). Body mass index (BMI) was calculated from height and weight measured during the in-home visit using a standardized protocol. Data on antihypertensive drug use was based on self-report, while use of digoxin, Coumadin, and statins were based on pill-bottle review. Digoxin was used as a proxy for heart failure as currently the only clinical indication for digoxin are heart failure and atrial fibrillation and digoxin use has a specificity of approximately $99 \%$ and sensitivity of $28 \%$ in heart failure diagnosis ${ }^{31}$. The CHADS2 score (congestive heart failure; hypertension; age, $\geq 75$ years; diabetes mellitus; and prior stroke) was calculated using 1 point for each category except for prior stroke, which was given 2 points ${ }^{32,33}$.

\section{Statistical Analysis}

Characteristics of the study sample were contrasted by PP categories at baseline. Logistic regression was used to calculate the odds ratio (OR) and 95\% confidence intervals $(\mathrm{CI})$ for the association between PP and AF. Multivariable models were adjusted as follows: Model 1 was the unadjusted model; Model 2 adjusted for age, gender, race, region, education, and income; Model 3 adjusted for Model 2 covariates plus history of vascular disease, history of coronary heart disease, left ventricular hypertrophy, diabetes, hypertension, heart failure, SBP, ACR, total cholesterol, HDL, log of hsCRP, BMI, smoking status, alcohol use. Model 4 adjusted for Model 3 covariates and antihypertensive medication use, and statin use. Additionally, tests of effect modification by age (dichotomized at 75), race (black vs white), gender (men vs. women), and region (stroke belt, stroke buckle, non-belt) were carried out. Statistical significance for all comparisons was defined as $\mathrm{p}<0.05$. SAS version 9.4 (SAS, Cary, NC) was used for all the analyses.

\section{RESULTS}

Of the 25109 participants included in the analysis; 8440 (33.6\%), 8194 (32.6\%), 5041 (20.1\%), and 3434 (13.7\%) participants had PP <45 mm Hg, 45-45.9 mm Hg, 55-64.9 mm $\mathrm{Hg}$ and $65.0+\mathrm{mm} \mathrm{Hg}$, respectively. Baseline characteristics for study participants stratified by PP group are shown in Table $1(\mathrm{~A} / \mathrm{B} / \mathrm{C})$. The prevalence of $\mathrm{AF}$ increased with widening PP (7.9\%, 7.9\%, 8.4\%, and $11.6 \%$ of the sample had AF for PP <45, 45-54.9, 55-64.9, and $\checkmark 65 \mathrm{~mm} \mathrm{Hg}$, respectively; $\mathrm{p}$ for trend $<0.001$ ) even in those receiving antihypertensive treatment (Table 1A).

The associations between PP and AF are shown in Table 2. In the unadjusted model, every $10 \mathrm{mmHg}$ increase in PP was associated with greater prevalence of AF, especially for a PP $\checkmark 65 \mathrm{mmHg}(\mathrm{OR}=1.53$ [95\% CI 1.34-1.75]). The association between PP and AF attenuated with full adjustment (Table 2).

In the analyses testing for effect modification of PP by age, gender, and region, only age was found to be a significant effect modifier ( $\mathrm{p}$ interaction=0.0002). The results of the agestratified analyses are presented in Table 3 . For those $<75$ years of age, PP $\ 65 \mathrm{mmHg}$ was significantly associated with higher risk of AF in both unadjusted and multivariable adjusted models. In contrast, higher PP (55-64.9 mmHg) was significantly associated with a lower risk of $\mathrm{AF}$ among those $\geq 75$ years of age. 


\section{Discussion}

In this analysis from the REGARDS study, higher PP was associated with a greater prevalence of AF. However, the association between PP and AF was attenuated after adjustment for sociodemographic factors, medical conditions, and physiological markers. However, the association between PP and AF was stronger in adults $<75$ compared to those who where $\geq 75$ years old.

The Framingham study reported that $\mathrm{PP}$ was associated with increased risk of $\mathrm{AF}^{12}$. It has also been reported that age is an independent clinical risk factor for $\mathrm{AF}^{34}$. PP serves as a surrogate measure of arterial stiffness and vascular aging and contributes to AF development. ${ }^{35,36}$ A significant correlation between PP and left atrial size independent of age, sex, and body surface area, was found in the Lifestyle Interventions and Independence for Elders (LIFE) sub study ${ }^{37}$. Furthermore, PP is associated with cardiovascular morbidity and mortality; and, this effect increases with age ${ }^{38-41}$. Our study found that the association between $\mathrm{AF}$ and PP was age dependent. Interestingly, adults $<75$ compared to $\geq 75$ years of age with higher PP had a greater risk of AF even after adjusting for all clinically significant variables including antihypertensive medications (Table 3 ). The explanation for this is not apparent, however, previous studies have speculated that the underlying mechanism between $\mathrm{PP}$ and AF is related to arterial stiffness that increases with age resulting in increased pulsatile load of blood on the heart ${ }^{42}$, promotion of left ventricular hypertrophy ${ }^{43}$, impairment of left ventricular diastolic relaxation ${ }^{44,45}$, and enlargement of left atrium ${ }^{42}$. Left atrial enlargement is an independent risk factor for AF resulting from fibrosis and remodeling of the atrium ${ }^{34,46}$. In a prospective study by Conan et a ${ }^{47}$, in individuals with normal left atrial size, age, height, hypertension, and exercise were significantly associated with incident AF. On the other hand, in individuals with left atrial enlargement only age and body weight were associated with incident AF. A study including participants from the Multi-Ethnic Study of Atherosclerosis, showed that for every 1 standard deviation increase in PP there was a 29\% increased AF risk ${ }^{13}$. Magnetic resonance imaging based aortic dispensability (as a measure of aortic stiffness) was not consistently associated with risk of AF. Based on these results they suggested that different mechanisms other than aortic stiffness may explain the PP and AF association, (eg left ventricular structural change and myocardial fibrosis). Therefore, the difference seen in our study between individuals $<75$ and $\geq 75$ years and the PP-AF association may be due to mechanisms other than left atrial enlargement and stiffness. Those mechanisms still need to be further elucidated in future studies. Moreover, the association between higher PP and lower risk of AF in those $\geq 75$ does not hold true in the group with a PP $>65 \mathrm{mmHg}$ after multivariable adjustment (Table 3). We do not have any clear explanation for this inconsistency.

The strength of this study is that we used a large national cohort that included a good representation of women and blacks as well as different socioeconomic status, assessed by income and education. To our knowledge, this is the first study showing that the association between PP and AF did not differ by race, gender, or region. Our study's limitations include the self-report of some variables (such as prior CHD and smoking, which is common in epidemiologic studies), relying on resting electrocardiograms and a participant's selfreported history of $\mathrm{AF}$ (likely underestimating the prevalence of AF e.g. we likely missed 
paroxysmal cases), diagnosis of heart failure based on digoxin (we might have excluded patients with diastolic heart failure), and the statistical use of multiple testing. Given the cross-sectional nature of our analysis, we could not establish the temporal relationship between AF and PP. Also, although we adjusted for several potential confounders, residual confounding remains a possibility.

In conclusion, in the REGARDS study PP was independently associated with AF, and the association of PP and AF differed by age; but after adjustment these associations were attenuated. Since PP increases with age, and PP is a potentially modifiable risk factor, ${ }^{13}$ targeted interventions to reduce PP particularly in adults $<75$ years has the potential to decrease AF risk, but longitudinal studies are needed to evaluate these observations.

\section{Acknowledgements}

This research project is supported by a cooperative agreement U01 NS041588 from the National Institute of Neurological Disorders and Stroke, National Institutes of Health, Department of Health and Human Service. The content is solely the responsibility of the authors and does not necessarily represent the official views of the National Institute of Neurological Disorders and Stroke or the National Institutes of Health. We are also supported by K24: 1K24HL111154 and REGARDS: R01HL080477. Representatives of the funding agency have been involved in the review of the manuscript but not directly involved in the collection, management, analysis or interpretation of the data. The authors thank the other investigators, the staff, and the participants of the REGARDS study for their valuable contributions. A full list of participating REGARDS investigators and institutions can be found at http://www.regardsstudy.org

\section{References}

1. Vlachopoulos C, Aznaouridis K, Stefanadis C. Prediction of cardiovascular events and all-cause mortality with arterial stiffness: a systematic review and meta-analysis. J Am Coll Cardiol. 2010; 55:1318-27. [PubMed: 20338492]

2. Cohn JN. Arterial stiffness, vascular disease, and risk of cardiovascular events. Circulation. 2006; 113:601-3. [PubMed: 16461830]

3. Chrysant SG, Chrysant GS. The age-related hemodynamic changes of blood pressure and their impact on the incidence of cardiovascular disease and stroke: new evidence. J Clin Hypertens (Greenwich). 2014; 16:87-90. [PubMed: 24373633]

4. Glasser SP, Halberg DL, Sands C, Gamboa CM, Muntner P, Safford M. Is pulse pressure an independent risk factor for incident acute coronary heart disease events? The REGARDS study. Am J Hypertens. 2014; 27:555-63. [PubMed: 24029164]

5. Blacher J, Pannier B, Guerin AP, Marchais SJ, Safar ME, London GM. Carotid arterial stiffness as a predictor of cardiovascular and all-cause mortality in end-stage renal disease. Hypertension. 1998; 32:570-4. [PubMed: 9740628]

6. Benetos A, Safar M, Rudnichi A, Smulyan H, Richard JL, Ducimetieere P, Guize L. Pulse pressure: a predictor of long-term cardiovascular mortality in a French male population. Hypertension. 1997; 30:1410-5. [PubMed: 9403561]

7. Cavalcante JL, Lima JA, Redheuil A, Al-Mallah MH. Aortic stiffness: current understanding and future directions. J Am Coll Cardiol. 2011; 57:1511-22. [PubMed: 21453829]

8. Go AS, Hylek EM, Phillips KA, Chang Y, Henault LE, Selby JV, Singer DE. Prevalence of diagnosed atrial fibrillation in adults: national implications for rhythm management and stroke prevention: the AnTicoagulation and Risk Factors in Atrial Fibrillation (ATRIA) Study. JAMA. 2001; 285:2370-5. [PubMed: 11343485]

9. Larstorp AC, Ariansen I, Gjesdal K, Olsen MH, Ibsen H, Devereux RB, Okin PM, Dahlof B, Kjeldsen SE, Wachtell K. Association of pulse pressure with new-onset atrial fibrillation in patients with hypertension and left ventricular hypertrophy: the Losartan Intervention For Endpoint (LIFE) reduction in hypertension study. Hypertension. 2012; 60:347-53. [PubMed: 22753219] 
10. Soliman EZ, Safford MM, Muntner P, Khodneva Y, Dawood FZ, Zakai NA, Thacker EL, Judd S, Howard VJ, Howard G, Herrington DM, Cushman M. Atrial fibrillation and the risk of myocardial infarction. JAMA Intern Med. 2014; 174:107-14. [PubMed: 24190540]

11. Bengtson LG, Lutsey PL, Loehr LR, Kucharska-Newton A, Chen LY, Chamberlain AM, Wruck LM, Duval S, Stearns SC, Alonso A. Impact of atrial fibrillation on healthcare utilization in the community: the Atherosclerosis Risk in Communities study. J Am Heart Assoc. 2014; 3:e01006. [PubMed: 25359400]

12. Mitchell GF, Vasan RS, Keyes MJ, Parise H, Wang TJ, Larson MG, D’ Agostino RB Sr. Kannel WB, Levy D, Benjamin EJ. Pulse pressure and risk of new-onset atrial fibrillation. JAMA. 2007; 297:709-15. [PubMed: 17312290]

13. Roetker NS, Chen LY, Heckbert SR, Nazarian S, Soliman EZ, Bluemke DA, Lima JA, Alonso A. Relation of systolic, diastolic, and pulse pressures and aortic distensibility with atrial fibrillation (from the Multi-Ethnic Study of Atherosclerosis). Am J Cardiol. 2014; 114:587-92. [PubMed: 24996553]

14. Mitchell GF, Izzo JL Jr. Lacourciere Y, Ouellet JP, Neutel J, Qian C, Kerwin LJ, Block AJ, Pfeffer MA. Omapatrilat reduces pulse pressure and proximal aortic stiffness in patients with systolic hypertension: results of the conduit hemodynamics of omapatrilat international research study. Circulation. 2002; 105:2955-61. [PubMed: 12081987]

15. Mitchell GF, Lacourciere Y, Ouellet JP, Izzo JL Jr. Neutel J, Kerwin LJ, Block AJ, Pfeffer MA. Determinants of elevated pulse pressure in middle-aged and older subjects with uncomplicated systolic hypertension: the role of proximal aortic diameter and the aortic pressure-flow relationship. Circulation. 2003; 108:1592-8. [PubMed: 12975261]

16. Zieman SJ, Melenovsky V, Kass DA. Mechanisms, pathophysiology, and therapy of arterial stiffness. Arterioscler Thromb Vasc Biol. 2005; 25:932-43. [PubMed: 15731494]

17. Soliman EZ, Prineas RJ. The paradox of atrial fibrillation in African Americans. J Electrocardiol. 2014; 47:804-8. [PubMed: 25112176]

18. Prineas RJ, Soliman EZ, Howard G, Howard VJ, Cushman M, Zhang ZM, Moy CS. The sensitivity of the method used to detect atrial fibrillation in population studies affects group-specific prevalence estimates: ethnic and regional distribution of atrial fibrillation in the REGARDS study. J Epidemiol. 2009; 19:177-81. [PubMed: 19561382]

19. Andrade J, Khairy P, Dobrev D, Nattel S. The clinical profile and pathophysiology of atrial fibrillation: relationships among clinical features, epidemiology, and mechanisms. Circ Res. 2014; 114:1453-68. [PubMed: 24763464]

20. Lip GY, Laroche C, Boriani G, Cimaglia P, Dan GA, Santini M, Kalarus Z, Rasmussen LH, Popescu MI, Tica O, Hellum CF, Mortensen B, Tavazzi L, Maggioni AP. Sex-related differences in presentation, treatment, and outcome of patients with atrial fibrillation in Europe: a report from the Euro Observational Research Programme Pilot survey on Atrial Fibrillation. Europace. 2015; 17:24-31. [PubMed: 24957921]

21. Conen D, Chae CU, Glynn RJ, Tedrow UB, Everett BM, Buring JE, Albert CM. Risk of death and cardiovascular events in initially healthy women with new-onset atrial fibrillation. JAMA. 2011; 305:2080-7. [PubMed: 21610240]

22. Dagres N, Nieuwlaat R, Vardas PE, Andresen D, Levy S, Cobbe S, Kremastinos DT, Breithardt G, Cokkinos DV, Crijns HJ. Gender-related differences in presentation, treatment, and outcome of patients with atrial fibrillation in Europe: a report from the Euro Heart Survey on Atrial Fibrillation. J Am Coll Cardiol. 2007; 49:572-7. [PubMed: 17276181]

23. Friberg J, Scharling H, Gadsboll N, Truelsen T, Jensen GB, Copenhagen City Heart S. Comparison of the impact of atrial fibrillation on the risk of stroke and cardiovascular death in women versus men (The Copenhagen City Heart Study). Am J Cardiol. 2004; 94:889-94. [PubMed: 15464671]

24. Howard VJ, Cushman M, Pulley L, Gomez CR, Go RC, Prineas RJ, Graham A, Moy CS, Howard $\mathrm{G}$. The reasons for geographic and racial differences in stroke study: objectives and design. Neuroepidemiology. 2005; 25:135-43. [PubMed: 15990444]

25. Lenfant C, Chobanian AV, Jones DW, Roccella EJ, Joint National Committee on the Prevention DE and Treatment of High Blood P. Seventh report of the Joint National Committee on the Prevention, Detection, Evaluation, and Treatment of High Blood Pressure (JNC 7): resetting the hypertension sails. Hypertension. 2003; 41:1178-9. [PubMed: 12756222] 
26. Soliman EZ, Howard G, Meschia JF, Cushman M, Muntner P, Pullicino PM, McClure LA, Judd S, Howard VJ. Self-reported atrial fibrillation and risk of stroke in the Reasons for Geographic and Racial Differences in Stroke (REGARDS) study. Stroke. 2011; 42:2950-3. [PubMed: 21817138]

27. Willenbring ML, Massey SH, Gardner MB. Helping patients who drink too much: an evidencebased guide for primary care clinicians. Am Fam Physician. 2009; 80:44-50. [PubMed: 19621845]

28. Harman J, Walker ER, Charbonneau V, Akylbekova EL, Nelson C, Wyatt SB. Treatment of hypertension among African Americans: the Jackson Heart Study. J Clin Hypertens (Greenwich). 2013; 15:367-74. [PubMed: 23730984]

29. Sokolow M, Lyon TP. The ventricular complex in left ventricular hypertrophy as obtained by unipolar precordial and limb leads. Am Heart J. 1949; 37:161-86. [PubMed: 18107386]

30. National Kidney F. K/DOQI clinical practice guidelines for chronic kidney disease: evaluation, classification, and stratification. Am J Kidney Dis. 2002; 39:S1-266. [PubMed: 11904577]

31. Fonseca C, Oliveira AG, Mota T, Matias F, Morais H, Costa C, Ceia F, Investigators E. Evaluation of the performance and concordance of clinical questionnaires for the diagnosis of heart failure in primary care. Eur J Heart Fail. 2004; 6:813-20. 821-2. [PubMed: 15542422]

32. Gage BF, Waterman AD, Shannon W, Boechler M, Rich MW, Radford MJ. Validation of clinical classification schemes for predicting stroke: results from the National Registry of Atrial Fibrillation. JAMA. 2001; 285:2864-70. [PubMed: 11401607]

33. January CT, Wann LS, Alpert JS, Calkins H, Cigarroa JE, Cleveland JC Jr. Conti JB, Ellinor PT, Ezekowitz MD, Field ME, Murray KT, Sacco RL, Stevenson WG, Tchou PJ, Tracy CM, Yancy CW, Members AATF. 2014 AHA/ACC/HRS guideline for the management of patients with atrial fibrillation: a report of the American College of Cardiology/American Heart Association Task Force on practice guidelines and the Heart Rhythm Society. Circulation. 2014; 130:e199-267. [PubMed: 24682347]

34. Psaty BM, Manolio TA, Kuller LH, Kronmal RA, Cushman M, Fried LP, White R, Furberg CD, Rautaharju PM. Incidence of and risk factors for atrial fibrillation in older adults. Circulation. 1997; 96:2455-61. [PubMed: 9337224]

35. Darne B, Girerd X, Safar M, Cambien F, Guize L. Pulsatile versus steady component of blood pressure: a cross-sectional analysis and a prospective analysis on cardiovascular mortality. Hypertension. 1989; 13:392-400. [PubMed: 2522417]

36. Franklin SS, Sutton-Tyrrell K, Belle SH, Weber MA, Kuller LH. The importance of pulsatile components of hypertension in predicting carotid stenosis in older adults. J Hypertens. 1997; 15:1143-50. [PubMed: 9350588]

37. Gerdts E, Papademetriou V, Palmieri V, Boman K, Bjornstad H, Wachtell K, Giles TD, Dahlof B, Devereux RB, Losartan Intervention For End point reduction in hypertension s. Correlates of pulse pressure reduction during antihypertensive treatment (losartan or atenolol) in hypertensive patients with electrocardiographic left ventricular hypertrophy (the LIFE study). Am J Cardiol. 2002; 89:399-402. [PubMed: 11835919]

38. Vaccarino V, Berger AK, Abramson J, Black HR, Setaro JF, Davey JA, Krumholz HM. Pulse pressure and risk of cardiovascular events in the systolic hypertension in the elderly program. Am J Cardiol. 2001; 88:980-6. [PubMed: 11703993]

39. Glynn RJ, Chae CU, Guralnik JM, Taylor JO, Hennekens CH. Pulse pressure and mortality in older people. Arch Intern Med. 2000; 160:2765-72. [PubMed: 11025786]

40. Mitchell GF, Parise H, Benjamin EJ, Larson MG, Keyes MJ, Vita JA, Vasan RS, Levy D. Changes in arterial stiffness and wave reflection with advancing age in healthy men and women: the Framingham Heart Study. Hypertension. 2004; 43:1239-45. [PubMed: 15123572]

41. Gardin JM, Arnold A, Gottdiener JS, Wong ND, Fried LP, Klopfenstein HS, O'Leary DH, Tracy R, Kronmal R. Left ventricular mass in the elderly. The Cardiovascular Health Study. Hypertension. 1997; 29:1095-103. [PubMed: 9149672]

42. Leite-Moreira AF, Correia-Pinto J, Gillebert TC. Afterload induced changes in myocardial relaxation: a mechanism for diastolic dysfunction. Cardiovasc Res. 1999; 43:344-53. [PubMed: 10536664]

43. Tsang TS, Gersh BJ, Appleton CP, Tajik AJ, Barnes ME, Bailey KR, Oh JK, Leibson C, Montgomery SC, Seward JB. Left ventricular diastolic dysfunction as a predictor of the first 
diagnosed nonvalvular atrial fibrillation in 840 elderly men and women. J Am Coll Cardiol. 2002; 40:1636-44. [PubMed: 12427417]

44. Abhayaratna WP, Barnes ME, O’Rourke MF, Gersh BJ, Seward JB, Miyasaka Y, Bailey KR, Tsang TS. Relation of arterial stiffness to left ventricular diastolic function and cardiovascular risk prediction in patients $>$ or $=65$ years of age. Am J Cardiol. 2006; 98:1387-92. [PubMed: 17134635]

45. Vaziri SM, Larson MG, Lauer MS, Benjamin EJ, Levy D. Influence of blood pressure on left atrial size. The Framingham Heart Study. Hypertension. 1995; 25:1155-60. [PubMed: 7768556]

46. Vaziri SM, Larson MG, Benjamin EJ, Levy D. Echocardiographic predictors of nonrheumatic atrial fibrillation. The Framingham Heart Study. Circulation. 1994; 89:724-30. [PubMed: 8313561]

47. Conen D, Glynn RJ, Sandhu RK, Tedrow UB, Albert CM. Risk factors for incident atrial fibrillation with and without left atrial enlargement in women. Int J Cardiol. 2013; 168:1894-9. [PubMed: 23333369] 


\section{Highlights}

- $\quad$ There are no racial, gender or regional differences in the relationship between pulse pressure and atrial fibrillation.

- $\quad$ In participants $<75$ years compared to those $\geq 75$ years, pulse pressure was associated with higher risk of atrial fibrillation

Pulse pressure is a potentially modifiable risk factor 


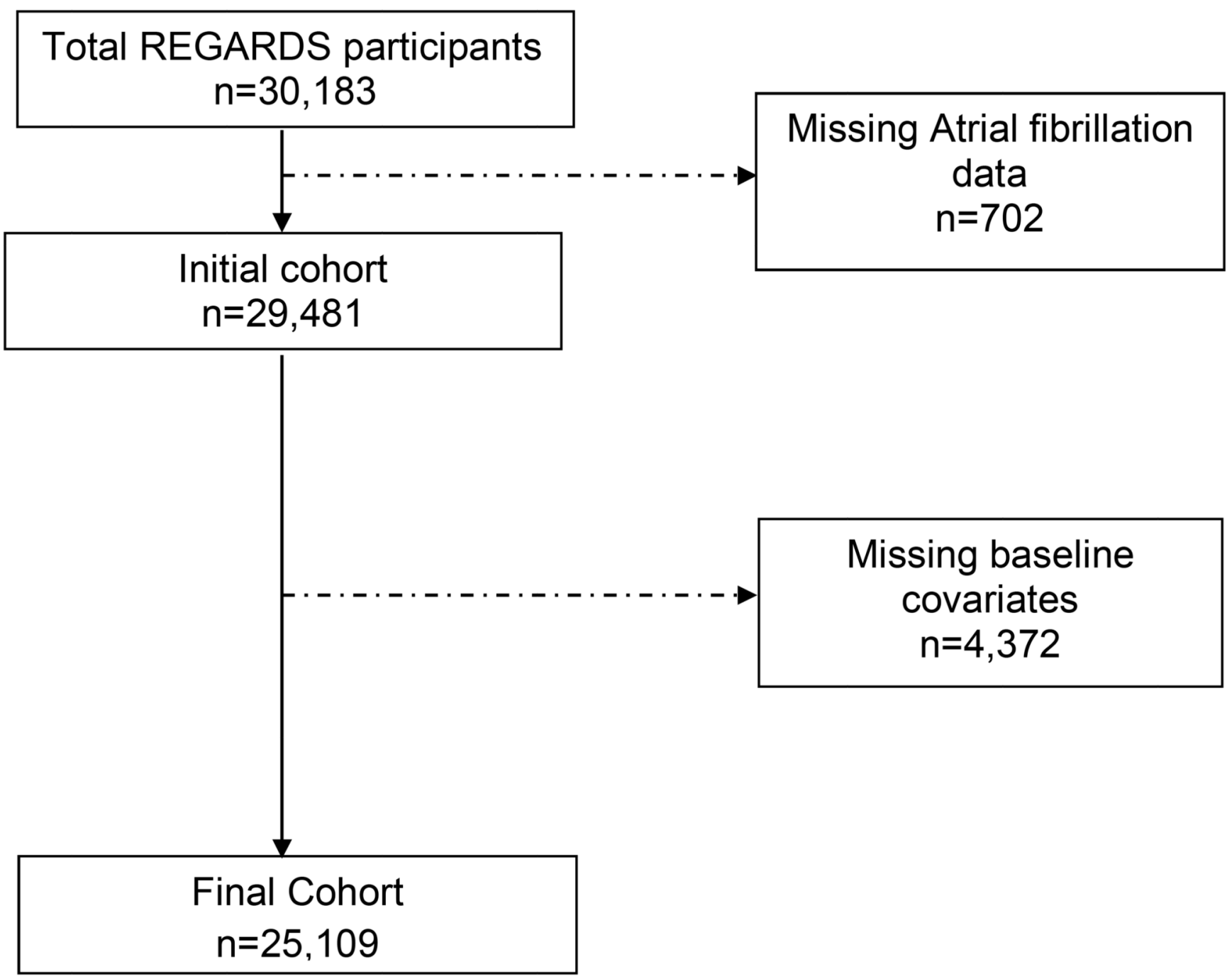

Figure 1. Exclusion cascade 


\section{Table 1A}

Baseline demographics of REGARDS participants by pulse pressure categories. $\mathrm{N}=25,109$

\begin{tabular}{|c|c|c|c|c|c|}
\hline Pulse Pressure & $\begin{array}{c}\leq 45 \mathrm{mmHg} \\
\mathrm{N}=8440\end{array}$ & $\begin{array}{c}\frac{45-54.9 \mathrm{mmHg}}{\mathrm{N}=8194}\end{array}$ & $\frac{55-64.9 \mathrm{mmHg}}{\mathrm{N}=5041}$ & 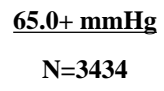 & $\underline{\text { P-value }}$ \\
\hline \multicolumn{6}{|l|}{ Demographics: } \\
\hline Age, years, Mean (SD) & $61.7 \pm 9.0$ & $64.4 \pm 9.0$ & $67.0 \pm 8.9$ & $70.0 \pm 8.8$ & $<.0001$ \\
\hline African Americans (\%) & 2993(35.5) & $3239(39.5)$ & $2166(42.9)$ & $1580(46.0)$ & $<.0001$ \\
\hline Females $(\%)$ & $4831(57.2)$ & $4326(52.8)$ & $2660(52.8)$ & $1730(50.4)$ & $<.0001$ \\
\hline \multicolumn{6}{|l|}{$\underline{\text { Region: }}$} \\
\hline Stroke Belt $(\%)$ & $2764(32.8)$ & $2895(35.3)$ & $1749(34.7)$ & $1252(36.5)$ & $<.0001$ \\
\hline Stroke Buckle (\%) & $1969(23.3)$ & $1706(20.8)$ & $975(19.3)$ & $651(18.9)$ & \\
\hline Non belt $(\%)$ & $3707(43.9)$ & $3593(43.8)$ & $2317(45.9)$ & $1531(44.6)$ & \\
\hline \multicolumn{6}{|l|}{ Socioeconomic status: } \\
\hline Income $<\$ 35 \mathrm{k}(\%)$ & $2960(35.1)$ & $3246(39.6)$ & $2380(47.2)$ & $1815(52.8)$ & $<.0001$ \\
\hline Education $<$ High school $(\%)$ & $710(8.4)$ & $925(11.3)$ & $716(14.2)$ & $650(18.9)$ & $<.0001$ \\
\hline \multicolumn{6}{|l|}{ Smoking: } \\
\hline Never $(\%)$ & $4078(48.3)$ & $3723(45.4)$ & $2183(43.3)$ & $1452(42.3)$ & $<.0001$ \\
\hline Past (\%) & $3146(37.3)$ & $3329(40.6)$ & $2105(41.8)$ & $1452(42.3)$ & \\
\hline Currently $(\%)$ & $1216(14.4)$ & $1142(13.9)$ & $753(14.9)$ & $507(14.8)$ & \\
\hline \multicolumn{6}{|l|}{ Alcohol Use (NIAAA): } \\
\hline Heavy $(\%)$ & $318(3.8)$ & $327(3.9)$ & $234(4.6)$ & $128(3.7)$ & $<.0001$ \\
\hline Moderate $(\%)$ & $3193(37.8)$ & $2788(34.0)$ & $1526(30.3)$ & $1030(29.9)$ & \\
\hline None $(\%)$ & $4929(58.4)$ & $5079(61.9)$ & $3281(65.1)$ & $2276(66.3)$ & \\
\hline \multicolumn{6}{|c|}{ Prevalence of Atrial Fibrillation (AF) } \\
\hline $\mathrm{AF}(\%)$ & $665(7.9)$ & $653(7.9)$ & $423(8.4)$ & $398(11.6)$ & $<.0001$ \\
\hline $\begin{array}{l}\text { AF among participants not } \\
\text { taking anti-HTN drugs }(\%)\end{array}$ & $311(6.2)$ & $244(6.0)$ & $122(6.2)$ & $95(8.8)$ & .0083 \\
\hline $\begin{array}{l}\text { AF among participants on } \\
\text { anti-HTN drugs }(\%)\end{array}$ & $354(10.4)$ & $409(9.9)$ & $301(9.9)$ & $303(12.9)$ & .0006 \\
\hline
\end{tabular}

NIAAA: National Institute on Alcohol Abuse and Alcoholism, HTN: Hypertension 


\section{Table 1B}

Baseline characteristics of REGARDS participants by pulse pressure categories. N=25,109

\begin{tabular}{|c|c|c|c|c|c|}
\hline$\underline{\text { Pulse Pressure }}$ & $\leq 45 \mathrm{mmHg}$ & $\underline{45-54.9 \mathrm{mmHg}}$ & & $\underline{65.0+} \mathrm{mmHg}$ & $\begin{array}{l}\text { P- } \\
\text { value }\end{array}$ \\
\hline & $\mathrm{N}=\mathbf{8 4 4 0}$ & $N=8194$ & $N=5041$ & $\mathrm{~N}=3434$ & \\
\hline \multicolumn{6}{|l|}{$\begin{array}{l}\text { Baseline medical } \\
\text { conditions: }\end{array}$} \\
\hline Hypertension (\%) & $3586(42.5)$ & $4467(54.5)$ & $3649(72.4)$ & 3099(90.2) & $<.0001$ \\
\hline $\begin{array}{l}\text { Stroke, PAD or aortic } \\
\text { aneurysm }(\%)\end{array}$ & $510(6.0)$ & $650(7.9)$ & $498(9.9)$ & $443(12.9)$ & $<.0001$ \\
\hline Coronary Heart Disease (\%) & $1081(12.8)$ & $1334(16.3)$ & 1027(20.4) & $869(25.3)$ & $<.0001$ \\
\hline $\begin{array}{l}\text { Left Ventricular Hypertrophy } \\
(\%)\end{array}$ & $595(7.1)$ & $799(9.8)$ & $551(10.9)$ & 493(14.4) & $<.0001$ \\
\hline Diabetes (\%) & $1127(13.4)$ & $1610(19.7)$ & $1277(25.3)$ & $1118(32.6)$ & $<.0001$ \\
\hline \multicolumn{6}{|l|}{ Physiologic Markers } \\
\hline SBP, mmHg, Mean (SD) & $114 \pm 10$ & $126 \pm 10$ & $136 \pm 11$ & $151 \pm 16$ & $<.0001$ \\
\hline DBP, mm Hg, Mean (SD) & $76 \pm 9$ & $77 \pm 9$ & $77 \pm 10$ & $76 \pm 12$ & 0.01 \\
\hline Renal Function: ACR >30 (\%) & $769(9.1)$ & $1045(12.8)$ & $932(18.5)$ & $948(27.6)$ & $<.0001$ \\
\hline Total Cholesterol , mg/dL & $193.5 \pm 39.1$ & $191.9 \pm 39.7$ & $191.0 \pm 40.0$ & $190.0 \pm 42.3$ & $<.0001$ \\
\hline $\mathrm{HDL}, \mathrm{mg} / \mathrm{dL}$ & $52.9 \pm 16.3$ & $51.3 \pm 15.8$ & $51.3 \pm 16.2$ & $50.9 \pm 16.2$ & $<.0001$ \\
\hline hsCRP, mg/L & $4.1 \pm 8.6$ & $4.4 \pm 7.4$ & $4.9 \pm 8.3$ & $5.3 \pm 9.0$ & $<.0001$ \\
\hline BMI, $\mathrm{kg} / \mathrm{m}^{2}$ & $28.6 \pm 6.0$ & $29.4 \pm 6.0$ & $29.7 \pm 6.2$ & $29.5 \pm 6.3$ & $<.0001$ \\
\hline \multicolumn{6}{|l|}{ Medications: } \\
\hline Antihypertensive Drugs (\%) & $3401(40.3)$ & $4137(50.5)$ & $3056(60.6)$ & $2349(68.4)$ & $<.0001$ \\
\hline Statins (\%) & $2281(27.0)$ & $2606(31.8)$ & $1748(34.7)$ & $1246(36.3)$ & $<.0001$ \\
\hline Digoxin $(\%)$ & $156(1.9)$ & $181(2.2)$ & $124(2.5)$ & $147(4.3)$ & $<.0001$ \\
\hline
\end{tabular}

PAD: peripheral arterial disease, SBP: systolic blood pressure, DBP: diastolic blood pressure, ACR: albumin to creatinine ratio, HDL: high-density lipoprotein, hsCRP: high sensitivity C - reactive protein, BMI: body mass index 
Table 1C

CHADS2 score for each pulse pressure category

\begin{tabular}{|c|c|c|c|c|c|}
\hline Pulse Pressure & $\begin{array}{c}<45 \mathrm{mmHg} \\
\mathrm{N}=8440\end{array}$ & $\begin{array}{c}45-54.9 \mathrm{mmHg} \\
\mathrm{N}=8194\end{array}$ & $\begin{array}{c}55-64.9 \mathrm{mmHg} \\
\mathrm{N}=5041\end{array}$ & $\frac{65.0+\mathrm{mmHg}}{\mathrm{N}=3434}$ & $\underline{\text { P-value }}$ \\
\hline \multicolumn{6}{|c|}{ CHADS2 Score for participants with Atrial Fibrillation, $\mathbf{n = 2 1 3 9}$} \\
\hline $0(\%)$ & $186(27.9)$ & $120(18.4)$ & $42(9.9)$ & $9(2.3)$ & $<.0001$ \\
\hline $1(\%)$ & 211(31.7) & 231(35.4) & 141(33.3) & $109(27.4)$ & \\
\hline$\geq 2(\%)$ & $268(40.3)$ & $302(46.2)$ & $240(56.7)$ & $280(70.4)$ & \\
\hline
\end{tabular}

HTN: Hypertension 
Table 2

Crude and Multivariable Adjusted Association of Atrial Fibrillation with Pulse Pressure

\begin{tabular}{|lcccc|}
\hline & Model 1 & Model 2 & Model 3 & Model 4 \\
\hline & OR (95\% CI) & OR (95\% CI) & OR (95\% CI) & OR (95\% CI) \\
Pulse Pressure & & & & \\
\hline$<45 \mathrm{mmHg}$ & REF & --- & --- & --- \\
$45-54.9 \mathrm{mmHg}$ & $1.01(0.91-1.13)$ & $0.93(0.83-1.05)$ & $0.90(0.79-1.03)$ & $0.91(0.80-1.03)$ \\
$55-64.9 \mathrm{mmHg}$ & $1.07(0.94-1.22)$ & $0.90(0.79-1.03)$ & $0.86(0.73-1.01)$ & $0.86(0.73-1.01)$ \\
$65.0+\mathrm{mmHg}$ & $\mathbf{1 . 5 3 ( 1 . 3 4 - 1 . 7 5 )}$ & $\mathbf{1 . 1 8 ( 1 . 0 3 - 1 . 3 6 )}$ & $1.06(0.85-1.31)$ & $1.07(0.86-1.33)$ \\
\hline
\end{tabular}

OR: odds ratio, REF: reference

Model 1 includes pulse pressure

Models 2 adjusts for age, gender, race, region, education, income

Model 3 adjusts for model 2 covariates and cardiovascular disease, coronary heart disease, left ventricular hypertrophy, diabetes, digoxin use, systolic blood pressure, albumin to creatinine ratio, total cholesterol, high-density lipoprotein, statins, log of high sensitivity C-reactive protein, body mass index, smoking, alcohol use

Model 4 adjusts for model 3 covariates and anti-hypertensive medications and baseline hypertension 
Table 3

Association of Prevalent Atrial Fibrillation with Pule Pressure stratified by age, younger $(<75)$ vs. older $(>75)$

\begin{tabular}{|c|c|c|c|c|}
\hline & Model 1 & Model 2 & Model 3 & Model 4 \\
\hline & $\mathrm{OR},(95 \% \mathrm{CI})$ & $\mathrm{OR},(95 \% \mathrm{CI})$ & $\mathrm{OR},(95 \% \mathrm{CI})$ & $\mathrm{OR},(95 \% \mathrm{CI})$ \\
\hline \multicolumn{5}{|c|}{ Age $(<75$ years $) n=20893$} \\
\hline \multicolumn{5}{|l|}{$\underline{\text { Pulse Pressure }}$} \\
\hline$<45 \mathrm{mmHg}$ & REF & --- & --- & --- \\
\hline $45-54.9 \mathrm{mmHg}$ & $0.96(0.84-1.09)$ & $0.91(0.80-1.03)$ & $0.89(0.77-1.03)$ & $0.89(0.77-1.04)$ \\
\hline $55-64.9 \mathrm{mmHg}$ & $1.07(0.93-1.25)$ & $0.97(0.84-1.13)$ & $0.94(0.78-1.13)$ & $0.93(0.77-1.13)$ \\
\hline $65.0+\mathrm{mmHg}$ & $1.66(1.42-1.94)$ & $1.43(1.21-1.68)$ & $1.31(1.02-1.68)$ & $1.32(1.03-1.70)$ \\
\hline \multicolumn{5}{|c|}{ Age $(=>75$ years $) n=4216$} \\
\hline \multicolumn{5}{|l|}{$\underline{\text { Pulse Pressure }}$} \\
\hline$<45 \mathrm{mmHg}$ & REF & --- & --- & --- \\
\hline $45-54.9 \mathrm{mmHg}$ & $0.96(0.75-1.22)$ & $0.97(0.76-1.25)$ & $0.94(0.71-1.24)$ & $0.94(0.71-1.25)$ \\
\hline $55-64.9 \mathrm{mmHg}$ & $0.69(0.53-0.89)$ & $0.70(0.54-0.91)$ & $0.66(0.47-0.91)$ & $0.65(0.47-0.90)$ \\
\hline $65.0+\mathrm{mmHg}$ & $0.76(0.59-0.98)$ & $0.78(0.60-1.02)$ & $0.70(0.46-1.05)$ & $0.69(0.46-1.04)$ \\
\hline
\end{tabular}

OR: odds ratio, Ref: Reference

Model 1 includes pulse pressure

Models 2 adjusts for age, gender, race, region, education, income

Model 3 adjusts for model 2 covariates and cardiovascular disease, coronary heart disease, left ventricular hypertrophy, diabetes, digoxin use, systolic blood pressure, albumin to creatinine ratio, total cholesterol, high-density lipoprotein, statins, log of high sensitivity C-reactive protein, body mass index, smoking, alcohol use

Model 4 adjusts for model 3 covariates and anti-hypertensive medications and baseline hypertension 